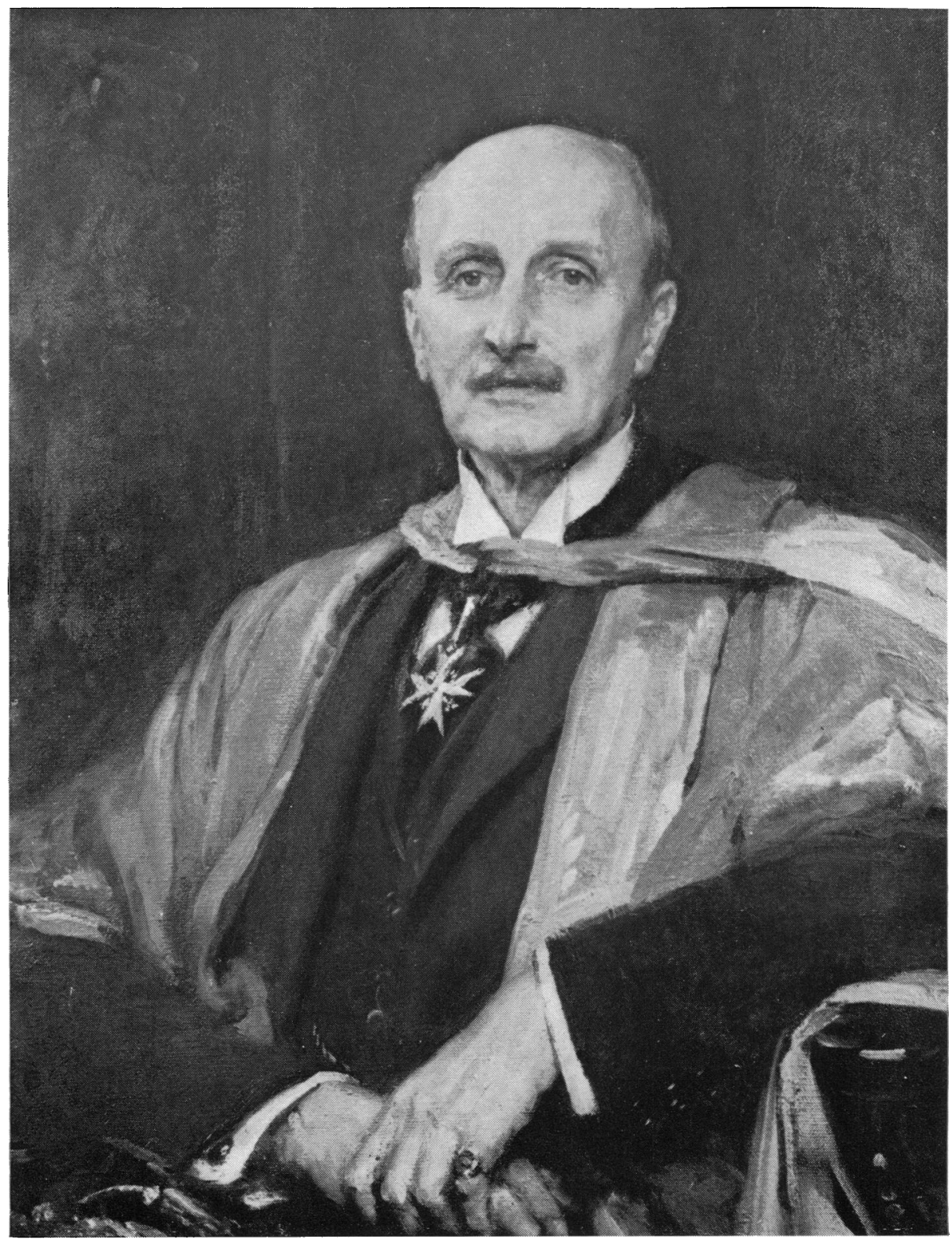

Sydney Arthur Monckton Copeman (1862-1947)

(From a portrait by Frank Eastman, R.A., in the possession of Dr. W. S. C. Copeman.) 


\section{THE PREVENTION OF SMALLPOX: FROM EDWARD JENNER TO MONCKTON COPEMAN*}

by

SIR ARTHUR SALUSBURY MACNALTY, K.C.B.

My first and pleasant duty is to express my thanks to the Faculty of the History of Medicine and Pharmacy of the Worshipful Society of Apothecaries for appointing me to give the Inaugural Monckton Copeman Lecture. In selecting the 'Prevention of Smallpox from Edward Jenner to Monckton Copeman' as the subject of the Lecture, I value the privilege of paying a tribute to two great benefactors of mankind. It is appropriate at the outset to give you some account of the man in whose memory this Lecture has been founded.

OUTLINE OF THE LIFE OF DR. S. MONCKTON COPEMAN

Sydney Arthur Monckton Copeman was born at Norwich on 21 February, 1862. His father was the Rev. Canon Arthur Charles Copeman, LL.D., Canon and Rural Dean of Norwich. Before taking Holy Orders, Canon Copeman qualified with the M.B. London in 1848, being gold medallist in anatomy and physiology. Preceding generations of the family were private bankers in Norwich; but medicine was further represented by the Canon's elder brother, Edward Copeman, M.D., F.R.C.P. (1809-1880), senior physician to the Norfolk and Norwich Hospital, the author of several books on obstetrics and gynaecology, who was President of the British Medical Association in 1874.

Monckton Copeman was educated at King Edward VI School, Norwich, and at Corpus Christi College, Cambridge, of which he was successively scholar, exhibitioner and prizeman. He graduated B.A. in the Natural Sciences Tripos in 1882, and entered on his clinical studies at St. Thomas's Hospital. His medical qualifications were as follows: M.B.Cantab. (1886); M.D. (1890); L.S.A.London (1885); L.R.C.P.London (1886); M.R.C.S. England (1887); and D.P.H., R.C.P.S. (1889); He was elected F.R.C.P. in 1899.

With the encouragement of Sir Michael Foster and later of Lord Lister, Copeman entered on physiological and medical research while he was demonstrator of physiology and morbid anatomy at his hospital. Later he became assistant lecturer in physiology and research scholar of the British Medical Association. His early researches were on the physiology and morbid conditions of the blood. With J. S. Bristowe he studied paroxysmal haemoglobinuria; and with C. S. Sherrington in the physiological laboratory of St. Thomas's Hospital he made observations on the variations experimentally produced in the specific gravity of the blood, and described a method for determining it in the living animal. He reported on the medico-legal detection of human blood and on the specific gravity of the blood in disease. As his grandson,

* The Inaugural Monckton Copeman Lecture delivered at Apothecaries' Hall, London, on 30 March 1967. 
Sir Arthur S. MacNalty, K.C.B.

Dr. Peter Copeman, has recently reminded $\mathrm{us}^{\mathbf{1}}$ he found haematoporphyrin in the urine of two patients suffering from an obscure disease now recognized as porphyria, the malady from which George III suffered, as lately shown by Dr. Ida MacAlpine and Dr. Richard Hunter, another brilliant piece of historic medical research. ${ }^{2}$ Monckton Copeman was also already searching for the active principle of vaccine lymph.

Sir Charles Sherrington informed me that he greatly valued Copeman as a collaborator and plans for further researches were maturing when Sir Richard Thorne Thorne, the Medical Officer of the Local Government Board, in 1891 secured Copeman's services as a Medical Inspector of the Board-'to my loss', added Sherrington. Thorne Thorne had been impressed by a report of Copeman's, which traced an outbreak of illness in Yorkshire to metallic poisoning. ${ }^{3}$ He spoke about the question of the appointment first with Sherrington, who advised Copeman to accept it.

From 1891, therefore, Copeman's active medical life was spent in the service of the Local Government Board and its successor, the Ministry of Health. At the Board he did his outstanding work on variola and vaccinia which will be described later.

For these researches he received many distinctions. In 1903 he was elected a Fellow of the Royal Society. He was awarded the Buchanan gold medal of the Royal Society in 1902; the Cameron Prize of the University of Edinburgh and the Fothergill gold medal of the Medical Society of London in 1899; the Jenner medal of the Royal Society of Medicine in 1925; and the gold medal of the International Faculty of Sciences in 1938.

In addition to smallpox prevention, Copeman did much work for the Central Health Department at home and abroad. He held local inquiries, investigated epidemics of scarlet fever, skin disease, enteric fever, cowpox and diphtheria. He early advocated immunization against diphtheria after studying the American and Canadian experience. He acted as government delegate to Germany, France, Austria, Switzerland and the United States in connection with investigations undertaken for the Home Office, the Board of Trade, the Local Government Board and the Ministry of Health, and served on many departmental committees. The annual reports of the Medical Officer of the Local Government Board from 1893 to 1919 and of the Chief Medical Officer of the Ministry of Health contain many of his contributions to knowledge of preventive medicine. He was lecturer in public health at Westminster Hospital, member of the Faculty of Medicine and Chairman of the Board of Studies in Hygiene of the University of London and examiner in public health at London and other universities. He was a Knight of Grace of the Order of St. John of Jerusalem and a member of the Chapter-General of the Order. He was also a founder of the Medical Research Club, served on the Council of the Royal College of Physicians and was president of the Epidemiological Society of the Royal Society of Medicine in 1926 and 1927.

Copeman also advanced military hygiene. He served as Divisional Sanitary Officer, 1st London Division of the Territorial Force, receiving the Territorial Decoration. During the war of 1914-18, with the rank of Colonel, he was in charge of the Hygiene Department of the Royal Army Medical College, and with others improved preventive 


\section{Prevention of Smallpox: From Edward Jenner to Monckton Copeman}

medicine in the field. In the later years of service as a medical officer of the Ministry of Health he paid special attention to the problem of cancer. He knew cancer and its research difficulties, and his advice and experience proved of great value to the Ministry of Health's Departmental Committee on Cancer. His last special report to the Ministry in 1925 gave an account of infestation in man by the nematode worm Ascaris lumbricoides, and has authoritative merit. ${ }^{4}$

He distinguished himself, as we have seen, in many fields of science and medicine with energetic endeavour. He was in addition an observant naturalist and biologist. As a Fellow and Member of the Council of the Zoological Society of London he guided its work on scientific lines. His prompt action in 1927 in dealing with an outbreak of anthrax prevented the spread of infection among the Society's keepers and animals.

Personal Characteristics. Copeman was tall and good-looking. He both wrote and spoke well. He was kind and generous, a good friend and adviser to his younger colleagues. We shared a room together at the Ministry of Health for several years; and I found him a delightful companion and admired his wide culture and scientific wisdom. He was an expert photographer and frequently used his camera to illustrate his medical, scientific and natural history writings.

In 1899 Copeman married Ethel Margaret, youngest daughter of Sir William Boord, Bt., M.P., of Wakehurst Place, Sussex. They had one son, Dr. W. S. C. Copeman, C.B.E., M.D., F.R.C.P., Past Master of this Worshipful Society and Chairman of the Faculty of the History of Medicine and Pharmacy, and two daughters.

Freeman of the City of London and Administrative work in Local Government. This Lecture has been founded also to perpetuate the medical history of London and its association with the Society of Apothecaries. Another aspect of Dr. Copeman's many interests illustrates this association. He was a Liveryman of the Society and a Freeman of the City of London. After his official retirement in 1925 he was a member of the London County Council and Chairman of the Public Health Committee of the Hampstead Borough Council. It was not until 1944 that failing eyesight and residence in Hampshire compelled him to relinquish these interests in which his experience and advice had been highly appreciated. His mental activities remained unimpaired and as long as he lived he kept himself informed of modern progress in medical research. He died at Hove on 11 April 1947.5

\section{EARLY TREATMENT OF SMALLPOX}

In the seventeenth century, and, indeed, well into the eighteenth century, the orthodox treatment of smallpox comprised isolation of the patient, rest in bed in a hot, ill-ventilated room, frequent blood-letting and over-drugging. Sydenham, who rejected the belief that the disease was contagious, said he saw no reason why the patient should be stifled in bed; and allowed him to rise and get up for a few hours every day. Sydenham's 'cooling method' was as follows: no fire in the room, windows open and bedclothes 'laid no higher than the waist.' For drink he allowed small beer. Under this mild treatment his patients did well, but few doctors adopted it, for his medical rivals stated that the whole of Sydenham's treatment of smallpox consisted in doing nothing. ${ }^{\circ}$ 
INOCULATION

When the eighteenth century was young the first steps in the prevention of smallpox by inoculation (Variolation) were made in Great Britain. Its initial traces are to be found in Asia and Africa (Klebs). The Chinese, the Brahmins of India, the Arabians and the Africans all knew from earliest times that the inoculation of matter from a mild case of smallpox often produced a slight form of the disease which would protect against a severe infection. In China the usual method was to insert smallpox crusts into the nostrils of the patient, whereby the disease was communicated through the respiratory tract. Variolation was also in early use in parts of Wales and in the Highlands of Scotland.

In the early eighteenth century inoculation was regularly practised in Turkey. In 1713 Dr. Emmanuel Timoni, a Greek physician in Constantinople, gave an account of this to the Royal Society. In 1716 Sir Hans Sloane, M.D., F.R.C.P., the President, described the practice of inoculation in Turkey in the Philosophical Transactions. His information was obtained from Dr. James Pylarini, who had published a dissertation on the subject in the previous year. As Copeman remarked:

But it would seem that their descriptions made little, if any, impression at the time, and, although published in the records of the Royal Society, passed at once into oblivion.?

Lady Mary Wortley-Montagu (1689-1762), whose letters adorn our literature, was the wife of Edward Wortley-Montagu, the British ambassador at Constantinople. In 1717 she had her son inoculated by Dr. Charles Maitland. On her return to this country she informed King George I of the method and urged its adoption in England. Six condemned criminals in Newgate were offered their freedom if they would be experimented upon. They consented and the test proved successful. The inoculation was done by Dr. Maitland in the presence of the great Dr. Mead and others. The king was afterwards inoculated by Amyand, the Serjeant Surgeon, with Maitland standing by. In the same year Queen Caroline, then Princess of Wales, and her two daughters were inoculated; and in 1724 the king sent Maitland to Hanover to inoculate his grandson Prince Frederick, afterwards Prince of Wales. This royal approbation partly allayed much opposition to the method and inoculation gradually made its way. In 1746 a hospital for the inoculation of the poor was established in London; and in 1754 the College of Physicians considered inoculation 'to be highly salutary to the human race.'

There was often risk of sepsis from inoculation but the technique of the method improved.

\section{MEAD, THE SUTTONS, ADAMS, DIMSDALE}

The spread of inoculation was due, indubitably, to the work of five leading persons in England. It was first favoured by the learned and eminent physician, Dr. Richard Mead (1673-1754), who watched the Newgate experiment, and had a great influence on the medical world in his day. In 1747 he published a book, De variolis et Morbillis, in which he strongly supported inoculation.

The brothers, Robert and Daniel Sutton, though without medical qualifications, practised inoculation successfully-Robert at Bury St. Edmunds, Suffolk, and Daniel 


\section{Prevention of Smallpox: From Edward Jenner to Monckton Copeman}

at Ingatestone, Essex. They combined it with Sydenham's 'cooling treatment'Daniel made only one puncture-and they claimed to have inoculated 20,000 persons without a single fatality. Another inoculator, named Adams, succeeded in obtaining a very attenuated virus which usually gave rise to only one vesicle at the site of puncture and a very mild form of smallpox.

A noteworthy inoculator was Thomas Dimsdale, M.D. (1712-1800), King's College, Aberdeen, and Estra-Licentiate of the College of Physicians, London. After serving as a surgeon in the ' 45 , he went into practice and in 1767 published a book on The Present Method of Inoculating for the Smallpox, which had a great vogue and made his reputation. In 1768 the Empress Catherine of Russia invited him to St. Petersburg where he inoculated, successfully, the Empress and her son, the Grand Duke Paul. He received a fee of $£ 10,000$ with $£ 2,000$ for travelling expenses, was created Baron, Councillor of State and physician to the Empress, and given an annuity of £500. On return to England he sat in two parliaments as M.P. for Hertford. In 1784 he again visited Russia to re-inoculate the Empress and inoculated her two grandsons, Alexander and Constantine. ${ }^{8}$

Despite royal and medical approval and successful results, there was much opposition to inoculation. Some of the clergy and their parishioners considered the remedy as unnatural and impious. William Heberden, junior, contended that by its means smallpox was spread, and, occasionally, deaths followed inoculation. Dimsdale, however, claimed that in his series of 1,500 cases no death had occurred. Certainly the inoculated patient, in many cases, spread smallpox to unprotected persons. Copeman observed that the records of the Smallpox Hospital for a series of years agree with Dr. Gregory's estimate of one death in 500 inoculated persons. He also quotes Sir Thomas Watson with approval. This distinguished physician said the method protected the individual but filled the country with contagion, so that while the relative mortality (the percentage of deaths from smallpox) was lessened by this practice the absolute mortality was fearfully increased. For this reason, as early as 1762, the practice of inoculation was made illegal in France. Further disadvantages were that inoculation kept smallpox alive in Great Britain, and in many cases the treatment was expensive, drastic and exhausting.

F. J. Fosbroke ${ }^{9}$ gave the following account of Edward Jenner's inoculation in 1760:

He was a fine, ruddy boy, and at eight years of age, was, with many others, put under a preparatory process for inoculation with the smallpox. This preparation lasted six weeks. He was bled to ascertain whether the blood was fine; he was purged repeatedly, till he became emaciated and feeble; was kept on a very low diet ... and dosed with a diet-drink to sweeten the blood. After this barbarism of human veterinary practice, he was removed to one of the usual inoculation stables and haltered up with others in a terrible state of disease.

This horrifying experience as a child assuredly inspired Jenner with a desire to prevent smallpox by some more humane method.

PRECURSORS OF JENNER

The milkmaids of Gloucestershire knew for a long time before Jenner's day that cowpox protected them from smallpox, though this belief was usually regarded as a piece of folklore. The first to inoculate cowpox as a safeguard against smallpox was 


\section{Sir Arthur S. MacNalty, K.C.B.}

Benjamin Jesty, a farmer of Yeominster in Dorsetshire, who, himself, had had cowpox by contagion from a cow. In 1714 he inoculated his wife and two sons, aged respectively three and two years with cowpox. His wife and family remained proof against smallpox inoculation and contagion.

Another cowpox inoculator was Peter Platt of Holstein. He was tutor in a family at Schönwade, Holstein, and learned from the milkmaids that cowpox protected them. Somewhat crudely, he vaccinated his employer's three children in 1791, by making incisions on the back of the hand between the thumb and forefinger. This was successful; and three years later when smallpox occurred in Schönwade, the vaccinated children were the only ones unattacked by the disease. Neither Jesty nor Platt went further; they were contented with their isolated success.

EDWARD JENNER

Edward Jenner was born on 17 May 1749, at Berkeley in Gloucestershire. He was the third son of the Rev. Stephen Jenner, Vicar of Berkeley. His mother was a daughter of the Rev. Henry Head, prebendary of Bristol. When Edward was five years old his father died; and the boy was brought up by his eldest brother, the Rev. Stephen Jenner, who also became Vicar of Berkeley, "with affectionate care and judicious guidance.'

Jenner early developed a liking for natural history and made collections of birds' eggs, plants and fossils. He had a brief five years' schooling, first at Wotton-underEdge and later at Cirencester. At 13 he was apprenticed to Mr. Daniel Ludlow, a surgeon at Sodbury. In 1770 he entered St. George's Hospital, and, when he was 21 he went as house pupil to John Hunter. Master and pupil soon became firm friends. Not only were they both interested in surgery, but their liking for natural history was another link, and Jenner must have learned much from Hunter about comparative anatomy. These two years were wonderful and happy for Jenner, when he sat at the feet of the great surgeon.

Jenner was not an ambitious man, and his heart was fixed on his birthplace. Amid the smoke and noise of London he longed for country air and peace in the pleasant Vale of Berkeley, where the River Severn after long wandering broadens as it winds towards the sea. So he discarded all opportunities for fame and fortune in London. For instance, one was John Hunter's offer of a share in the school of natural history which Hunter proposed starting; another was the post of naturalist in the next expedition of Captain Cook. Jenner had arranged and catalogued the botanical specimens brought home by Joseph Banks (afterwards Sir Joseph Banks, Bt., P.R.S.) who accompanied Cook as naturalist in his first expedition. Instead, Jenner returned to Berkeley where he led the life of a country doctor and found time for natural history. Hunter corresponded with him and often suggested experimental researches.

In 1778, when Jenner was crossed in love Hunter wrote:

I own I was glad when I heard you was married to a woman of fortune; but let her go, never mind her. I shall employ you with Hedge Hogs, for I do not know how far I may trust mine.

An unusual consolation for a disappointed lover!

Like Sir Walter Scott, Jenner's heart 'was handsomely pieced.' In 1788 he married 


\section{Prevention of Smallpox: From Edward Jenner to Monckton Copeman}

Catherine Kingscote. They had three children; Edward who died young of consumption, Catherine and Robert. John Hunter was godfather to Edward.

It was concerning hedgehogs that Hunter gave his memorable and most valuable advice to Jenner: 'I think your solution is just; but why think, why not try the experiment?'

Soon after Jenner had settled at Berkeley, Hunter asked him to study the natural history of the cuckoo. Jenner's observations were prolonged, and it was not until the winter of 1786-7 that he drafted a letter which Hunter presented to the Royal Society as a paper on 29 March 1787. Jenner made some further important observations and included these in an expanded and revised paper which was also sponsored by Hunter and read to the Royal Society on 27 December 1787. It was published in 1788 in the Philosophical Transactions. In this paper Jenner describes the wanton behaviour of the female cuckoo, attended by several male cuckoos; her laying of eggs in other birds' nests; the feeding of the rapacious interloper by the deluded foster-parents; the ability of the two-day-old cuckoo to throw a young nestling, for instance a hedge-sparrow, out of the nest; and the appearance of a temporary depression on the infant cuckoo's back, which serves as a cup for the unhatched eggs or freshly hatched nestling about to be thrown out.

Jenner's careful observations were received with surprise and even incredulity up to modern times. Waterton, an eccentric traveller and naturalist, attacked their truth, and Sir Norman Moore said in the Dictionary of National Biography that Waterton had demonstrated their absurdity. Charles Creighton said that as Jenner was wrong about the cuckoo, therefore he must be wrong about vaccination! LeFanu points out that Jenner's description has been confirmed by photography. F. Howard Lancum showed, in 1929 a series of lantern slides, reproducing 'the first photographs which clearly illustrate the various stages of the eviction process.' R. H. Burne, F.R.S., physiological curator of the Hunterian Museum, demonstrated the hollow in the back of the young cuckoo in preparations.

Jenner was elected F.R.S. on 25 February 1789, 'a formal recognition of his scientific ability long known to Banks and Hunter.'

Jenner's other paper to the Royal Society was on the 'Migration of Birds', and was left unfinished. When it was written the fact of migration was still doubted, but Jenner established it, and also the prime cause 'to produce an offspring'.

\section{WRITINGS ON CLINICAL SUBBCTS}

In LeFanu's valuable and comprehensive bibliography accounts are given of Jenner's writings on clinical subjects. The most outstanding are as follows: (1) His lost paper entitled: 'Remarks on a disease of the heart following acute rheumatism, illustrated by dissections', read to the Society for the Improvement of Medical and Chirurgical Knowledge on 3 April 1810 and published in that Society's Transactions, 1812, Vol. 3. pp. 383-424. Apparently, this paper anticipated the findings of later investigators. (2) Letter to Caleb Hillier Parry on angina pectoris in Parry's Inquiry into the syncope anginosa, 1799, pp. 3-5. Jenner concluded that 'ossification or malorganisation was the cause of the disease', and mentioned that he had told his fears about angina pectoris in John Hunter's case to Cline and Sir Everard Home who 


\section{Sir Arthur S. MacNalty, K.C.B.}

had informed him of the confirmatory post-mortem findings. Jenner's reputation was high as a diagnostician, and he seems to have been often called into consultation by Parry of Bath and others.

Poetry: Jenner was also a poet. Many of his verses are slight, epigrams or impromptu vers d'occasion, but some are of more merit, as 'To a Robin', 'Signs of Rain', and 'Berkeley Fair'.

So far Jenner's life was that of a pupil of John Hunter, a competent general practitioner, as a scientist, field naturalist and a Fellow of the Royal Society. It was the prologue to world-wide and lasting fame.

\section{DISCOVERY OF VACCINATION}

At Sodbury, when, a medical student, Jenner had been told by a milkmaid: 'I cannot take smallpox, for I have had cowpox'. He told John Hunter who mentioned the tradition in his lectures. Jenner discussed it at local medical societies, but, again, it was usually regarded as folklore or legend. He thought deeply on the matter and remembered Hunter's advice to experiment. The opportunity came when Sarah Nelmes, a milkmaid, showed her hand infected with cowpox to Jenner. A drawing was made of it; and James Phipps, a healthy boy of eight years, was vaccinated in two places by Jenner with lymph from one of the vesicles in Sarah's hand on 14 May 1796 , a red-letter day in the history of preventive medicine. On 1 July Jenner wrote to his friend Gardner:

The boy has since been inoculated for the smallpox, which as I ventured to predict, produced no effect. I shall now pursue my experiments with renewed ardour.'

Afterwards there was no cowpox in the dairies for two years, and therefore, no material for experiments. In 1798 it returned and Jenner made further vaccinations. In the same year he published the first edition of his famous Inquiry as a pamphlet. ${ }^{10}$ After describing the disease of horses called 'grease', he said it was identical with cowpox of which he gave a clinical description. He maintained three propositions: (1) The virus must be acquired by the cow after its passage through the horse. (2) Only the true virus gives protection against smallpox. (3) It gives permanent protection. [This was an error because revaccination has been found necessary to ensure protection throughout life.]

Evidence of the efficacy of vaccination is given in twenty-three case-histories. In one case (case 4) he gives the first account of the phenomenon of anaphylaxis. In 1799 Jenner issued an account of his Further Observations. In 1800 he published A Continuation. This was issued with the previous pamphlets as the second edition of the Inquiry with a new dedication to King George III. For further editions and foreign translations; see LeFanu. ${ }^{\circ}$

The Inquiry was read not only by doctors and scientists but by the intelligent lay public. Jane Austen described an instructive evening spent in hearing Dr. Jenner's Inquiry read aloud. The Inquiry had a mixed reception. The caricaturists made fun of vaccination depicting persons with horns and cows' heads growing from their bodies as its result. The inoculators opposed Jenner. Dr. Rowley of Oxford published a pamphlet with the title, 'Cow-pox Inoculation no Security against Smallpox In- 


\section{Prevention of Smallpox: From Edward Jenner to Monckton Copeman}

fection', figuring a boy who was stated to have an ox-face after vaccination. Misguided clergymen preached sermons on the sinfulness of vaccination. Cases were published in which smallpox had occurred after vaccination. Probably, the patients were previously incubating the disease. Harm to the method was also due to a Dr. Woodville who distributed lymph from the Smallpox Hospital which he called 'Jenner's lymph', all over Europe. Jenner explained this lymph had been contaminated with smallpox virus. It produced a mild general smallpox eruption.

So fearful were the ravages of smallpox and so ineffective was inoculation in checking epidemics of it that the practice of vaccination steadily made its way. Without consulting Jenner, an institution for free vaccination, with royal patronage, had been set up by Dr. Woodville, Dr. Pearson and others. Jenner disapproved of the organization, and refused to be an 'Extra Consulting Physician'. The Duke of York and others withdrew their patronage.

In 1800 Jenner was presented to the King, the Queen and the Prince of Wales by Lord Berkeley. The King graciously accepted a copy of the Inquiry. In 1792 Jenner had been given the M.D. degree of St. Andrews University on the recommendation of J. H. Hickes of Geneva and C. H. Parry, M.D., of Bath. In 1813 he received an honorary M.D. from the University of Oxford, a rare distinction. In those days the statutes of the College of Physicians prohibited the admission of a fellow unless he passed the required examination in Latin, so Jenner never became one, although some of his friends made an application to the College on his behalf.

By this time his fame was world-wide. When Jenner applied for the release of two British friends imprisoned in France after the Peace of Amiens had been broken, Napoleon granted the request, saying, 'Ah, Jenner! We can refuse nothing to that man'. In June 1802 a grant of $£ 10,000$ was made by Parliament to Jenner; and in July 1807 Parliament made a further grant of $£ 20,000$. It was pointed out that he had reaped no advantage from his great discovery; and that he had suffered financially from devoting so much time to vaccination both in medical practice and in out-ofpocket expenses.

Many honours from all quarters of the globe were bestowed on Jenner. He was made an honorary fellow of numerous medical and scientific societies, received the Freedom of the City of London in a gold box, which is now the property of our Worshipful Society; the Freedoms of Edinburgh, Glasgow, Liverpool, Dublin and Kirkaldy; a letter signed 'Marie' from the Dowager Empress of Russia with a ring set in diamonds; the diploma of LL.D. from Harvard University; and numerous gold and silver medals struck in his honour. In 1821 he was appointed Physician Extraordinary to King George IV.

After Parliament had awarded Jenner the first grant, with much reluctance, he was persuaded by $\mathrm{Mr}$. Addington, the Prime Minister, and others to practise in London from a house in Hertford Street, Mayfair; but after three months' trial he returned to Berkeley.

THE NATIONAL VACCINE ESTABLISHMENT OF THE COLLEGE OF PHYSICIANS

In 1808 Parliament, having received a report from the College of Physicians in which they strongly recommended vaccination, called upon the College to appoint 
a medical board to inquire into the methods of vaccination generally used, with their success or failure; and to organize and superintend a Central Institution for the practice of vaccination, and for distributing lymph to every part of the British Dominions. From 1808 to 1826 the Board consisted of the President and Censors of the College of Physicians, and the Master and two Wardens of the College of Surgeons. In 1826 the numbers were reduced to five.

Jenner, at the request of Sir Lucas Pepys, the President, drew up plans and an estimate of expenses for the National Vaccine Establishment. He was in London for five months helping to organize it, and then returned home. Later he learned that he was to be styled 'Director' but without a seat on the Board. He refused to accept this nominal office, but offered to help with any advice unofficially. He did so more frequently when his friend, Dr. James Moore, brother of Sir John Moore who died at Corunna, was afterwards the Director.

\section{EFFICACY OF VACCINATION}

Jenner was cheered by the following reports:12

(1) In Havana, where smallpox had been extremely fatal, no death had occurred over a two year period. (2) In Spanish America, Milan and Vienna smallpox had been 'extinguished'. The previous annual mortality from smallpox in Vienna had averaged 800 persons. (3) In France out of 2,671,662 persons vaccinated only 7 had taken smallpox. (4) In Russia 1,235,597 persons had been vaccinated in 8 years. (5) Millions had been vaccinated in the Old and New Worlds in the few years that had elapsed since Jenner published his Inquiry.

\section{LAST YEARS AND DEATH}

After his wife's death in 1815 Jenner lived almost entirely at Berkeley. He continued to practise as a country doctor, performed his duties as a local magistrate and found solace in his favourite pursuit of natural history. He died suddenly of cerebral haemorrhage, on 24 January 1823, and was buried in the chancel of Berkeley Church. ${ }^{11,12}$

Jenner's work, based on careful scientific experiments, has inspired others who have made epoch-making discoveries. Especially is this true of Louis Pasteur, who always describes his researches as inspired by Jenner. Pasteur's work, as you know, in turn inspired Joseph Lister's discovery of antiseptic surgery a hundred years ago.

When Jenner discovered that vaccine lymph protected against smallpox he founded immunology; although, as H. J. Parish observed, ${ }^{13}$ it was 200 years before this became a science. Noble and far-reaching was the heritage Jenner bequeathed to mankind.

THE SUPPLY OF VACCINE LYMPH AFTER JENNER

In 1832 the officers of the National Vaccine Establishment supplied 100,513 charges of lymph to 6,850 applicants and themselves vaccinated 14,190 persons. In this year the London Vaccine Institution, which continued as an independent body, supplied 43,164 charges and vaccinated 5,641 persons. During a period of exceptional prevalence of smallpox in the years 1837-1839 the National Vaccine Establishment 


\section{Prevention of Smallpox: From Edward Jenner to Monckton Copeman}

issued 203,813 charges of lymph in the first year and 665,395 in the second. This epidemic, which continued in the manufacturing towns until 1841, was fatal chiefly to infants and young children. As a result of it inoculation for smallpox was prohibited under penalties by legislation (the Vaccination Act, 1840), with provision for the poor to get their children vaccinated, if they so wished, at the cost of the ratepayers; and the Guardians or Overseers in every district were to contract with their medical officer or other medical practitioners for vaccination. The Vaccination Act of 1867 required Boards of Guardians to separate parishes into Vaccination Districts and to contract with a medical practitioner as Public Vaccinator. The Public Health Act of 1848 constituted the General Board of Health.

In 1853 the Compulsory Vaccination Act was passed, but did not provide adequate powers for its enforcement. This was remedied as the result of a report to the President of the Board by John Simon in 1857. The Public Health Act of 1858 embodied his recommendations. The Privy Council, which had taken over the health and medical powers of the General Board of Health, was also empowered in 1861 to take over the work of the National Vaccine Establishment; and thus after fifty years the association of the College of Physicians with vaccination was ended. Only qualified medical practitioners were now permitted to vaccinate; and Educational Vaccination Stations were set up at which authorised Public Vaccinators instructed pupils for six weeks and, if satisfied, gave them a certificate of proficiency in vaccination.

The Privy Council directed the work of the National Vaccine Establishment, supervised its working and standardised and distributed the lymph from 1861 to 1871. The Local Government Board undertook this responsibility from 1871 to 1919 , and then its successor, the Ministry of Health, took over the work. ${ }^{14}$

THE GREAT EPIDEMIC OF SMALLPOX, 1871-1872

Outbreaks of smallpox had occurred in the intervening years between 1841 and 1871 , but not on any large scale. In its first year the Local Government Board was faced with the great epidemic of 1871-1872. This epidemic exploded suddenly, prevailing in the towns and industrial counties, especially in London, and attacked young persons and adults more than infants and children. Since 1841 a whole generation had grown up for the most part unprotected from smallpox. For an account of this epidemic and of antecedent epidemics of smallpox Creighton's A History of Epidemics in Britain ${ }^{15}$ should be consulted.

\section{ARM-TO-ARM VACCINATION}

When Copeman became a medical inspector of the Local Government Board in 1891, arm-to-arm vaccination was commonly practised. The objections to it were as follows: (1) the possible attenuation of the virus by repeated human transmission. Jenner originally referred to this risk. (2) The danger of transmitting other diseases along with vaccinia. The serious diseases that might be so conveyed were erysipelas, tuberculosis and syphilis. Dr. Cory in an experiment similar to and as disastrous as that of John Hunter, acquired the last-named disease by inoculating himself with lymph taken from the arm of a syphilitic infant. Sepsis was another hazard; this was brought about, either by accidental injuries or by the use of unsterilized dressings. 


\section{CALF-TO-ARM VACCINATION}

Following on the results of investigations made by Sir George Buchanan, the elder, and Dr. Cory, direct vaccination of lymph from calf to arm was done at the Government Animal Vaccine Establishment at Lamb's Conduit Street and at the National Vaccine Station established at St. Mary Abbots, Kensington, with Dr. Cory as Director, in 1881. The lymph sent out was usually preserved by drying on ivory points. Calf-to-arm vaccination also presented difficulties and was not always successful. Sir George Buchanan, as Medical Officer of the Local Government Board, urged caution in adopting the method instead of arm-to-arm vaccination in view of its uncertainty, as a large proportion of calf lymph failed to take. Copeman began his great research by investigating this question.

\section{COPEMAN'S TRIUMPH BASED ON SCIENTIFIC INVESTIGATION}

Copeman first proved that the lack of efficacy observed with calf lymph was because the lymph lost its potency when kept in the fluid state dried on ivory points and was less reliable than humanized lymph. The experiments made to overcome these defects led him to make his great practical discovery. He first tried exposing the lymph to temperatures which should kill the bacteria present in it. The results were conflicting and unsatisfactory. In his own words:

Some method of readier application and requiring less delicate manipulation was therefore obviously desirable. This I at length found in the addition to the lymph or rather to the vesicular pulp obtained from a vaccinated calf, of a selected 50 per cent solution of glycerine in distilled water. (Milroy Lectures, 1898, Chap. IV).

Copeman, as he always acknowledged, was not the first to add glycerine to vaccine lymph. Dr. R. R. Cheyne, in the Medical Times in 1850, advocated this practice. On the continent of Europe others also used glycerine for diluting and preserving vaccine lymph, for example, in vaccine establishments in France, Belgium, Holland and Germany. Müller reported, in 1869, that vaccine lymph could be diluted with three times its bulk of glycerine and yet remain effective. These previous observations in no way detract from the merit of Copeman's discovery, for he was the first to demonstrate the selective germicidal action on the extraneous bacteria of calf vaccine lymph. When this was proved as a scientific fact, suitable techniques of preparing glycerinated calf lymph were devised.

In 1896 and in 1897 Dr. Copeman with the Medical Officer of the Local Government Board, Sir Richard Thorne Thorne, visited Paris, Brussels, Berlin, Cologne, Dresden and Geneva to ascertain the methods in these cities respecting the distribution of vaccine lymph including its preparation and storage. They were pleased to find that since Copeman's results had been published, in each of the countries visited, vaccination with glycerinated calf lymph had become almost universal. This was notably so in Germany where arm-to-arm and calf-to-arm vaccinations had been abandoned.

After these visits Sir Richard Thorne Thorne recommended: (1) that vaccination, both primary and secondary, carried out under the auspices of the British Government, should be performed exclusively with vaccine lymph derived from the calf; (2) that the distribution of calf vaccine from the National Vaccine Establishment 


\section{Prevention of Smallpox: From Edward Jenner to Monckton Copeman}

should be limited to glycerinated or similar preparations of lymph and pulp material, in air-tight tubes, or other glass receptacles; (3) that the Board's Animal Vaccine Station should be reorganized both as regards construction and administration, and that it should include a properly equipped bacteriological laboratory under the direct supervision of a bacteriological expert.

These recommendations were given effect by the provision of the Vaccination Act of 1898 and the Vaccination Order (1898) of the Local Government Board, and a new laboratory was provided at Chelsea under the charge of Dr. F. R. Blaxall. The distribution of glycerinated calf-lymph began on 1 January 1899. By 1907 the work had so greatly increased that a new institution known as the Government Lymph Establishment was set up under the direction of Dr. Blaxall, where the whole process of vaccination lymph manufacture and distribution was done. Thus, as a result of Copeman's work, arm-to-arm vaccination was abolished and vaccination was made a much simpler and safer operation.?

\section{FROM COMPULSION TO ITS ABOLITION}

To complete the account of administrative vaccination, it should be said that in spite of vaccination against smallpox having been made compulsory before the age of three months, in 1853, a high proportion of protected infants was not obtained, and from 1889 to 1896 a Royal Commission inquired into the vaccination laws. Its principal findings based on Copeman's researches have already been mentioned as embodied in the Vaccination Act of 1898. This Act also announced that glycerinated calf-lymph or such other lymph as may be issued by the Local Government Board would be supplied gratuitously to public vaccinators. It may be mentioned here that the Public Health (Smallpox Prevention) Regulations, 1917, gave a medical officer of health power to vaccinate or re-vaccinate without charge any contacts of a case of smallpox willing to submit themselves to the operation. The administration of vaccination was transferred to County Councils and County Borough Councils from Boards of Guardians by the Local Government Act of 1922, and the medical officer of health became the public vaccinator.

In 1899 when the Vaccination Act of 1898 came into force the Government issue of glycerinated calf-lymph amounted to 499,281 capillary tubes. A severe outbreak of smallpox in London and Liverpool in 1901 approximately doubled this issue, and greatly strained the resources of the National Vaccine Establishment. New laboratories for calf vaccination, lymph manufacture and despatch were opened in 1907. Dr. Blaxall died in 1930. His successor, Lt.-Col. Stevenson, died in 1945. Dr. Butler was in charge until 1946 when the Establishment closed. The Medical Research Council through its Committees now guides the Ministry of Health on the scientific aspects of immunization.

As already noted, in 1898 an Act of Parliament allowed conscientious objectors to be excused vaccination. Thereafter, only a minority of children were vaccinated. In 1946 the proportion of children vaccinated was only 41.5 per cent (half the rate protected in 1898), and compulsory vaccination was discontinued.

COPEMAN'S FURTHER WORK ON VARIOLA AND VACCINIA

Other work done by Copeman on variola and vaccinia was the following: He 


\section{Sir Arthur S. MacNalty, K.C.B.}

succeeded in transmitting smallpox to monkeys, a possibility which had been authoritatively denied; and demonstrated in them cross-immunity between vaccinia and variola. He also succeeded in transmitting variola to the calf, and noted that the reaction became modified in the course of successive removes, and that inoculated calves are resistant to vaccination. These experiments were done at the Brown Institution with antiseptic precautions. With Dr. Gustav Mann of the Oxford School of Physiology he described the histology of vaccinia ${ }^{16}$ and also studied other features of variola and vaccinia.

Copeman chiefly recorded his important researches in the Proceedings of the Royal Society 1893, the Transactions of the Epidemiological Society 1891-93, the Annual Reports of the Medical Officer of the Local Government Board, and his comprehensive Milroy Lectures on 'Vaccination: Its Natural History and Pathology' delivered to the Royal College of Physicians in 1898. He also wrote the article on 'Pathology of Vaccination' in Allbutt's System of Medicine.

In spite of much official work in other fields of preventive medicine, Copeman retained his interest in smallpox in his later life. His advice was notably of value in alastrim and post-vaccinial encephalomyelitis.

\section{VARIOLA MINOR OR ALASTRIM}

From time to time a benign form of smallpox prevailed in many parts of the world including South Africa. Known as variola minor or alastrim (the Kaffir name for the disease) it first appeared in Great Britain in Norfolk and Suffolk in 1919 and affected 19 persons. It was identified as alastrim, a mild form of smallpox, by Copeman who reported on it. ${ }^{17}$ Between 1923 and 1924 there were over 80,000 cases in England, the disease having become endemic. Afterwards it disappeared until 1951 when 145 cases were reported in Rochdale. It reappeared in 1966 in a small outbreak in the Midlands. Cases also occurred in Monmouthshire, Salford, Lancashire, and Warwickshire. ${ }^{18,19}$

J. Pickford Marsden made a clinical study of 13,686 patients with alastrim treated in the London Smallpox Hospitals. ${ }^{20}$ The mortality rate was 0.25 per cent as compared with a mortality rate of 32 per cent in smallpox (variola major). In both types of smallpox the early symptoms - headache, backache, vomiting, shivering and pains in the chest-are the same. The rash also appears on the third or fourth day, but the lesions are more superficial. Alastrim breeds true, only a mild illness following contact infection. Vaccination is an efficient prophylactic.

Copeman studied alastrim with interest, visited a number of patients, and took photographs of the rashes which he showed and explained to me and other colleagues. Fortunately, as I have said, smallpox vaccination protects against alastrim and the disease never reverts to virulent smallpox. The two viruses are serologically indistinguishable; they can be separated by their different pathogenicity for the chick embryo.

The virus of variola minor is unable to produce pocks on the chorio-allantoic membrane at $38.5^{\circ} \mathrm{C}$., though the pock producing capacity of the virus of classical smallpox is unaffected at this temperature. ${ }^{21}$

Contacts of alastrim should be vaccinated, kept under observation, and the usual measures of isolation and disinfection carried out. 


\section{Prevention of Smallpox: From Edward Jenner to Monckton Copeman}

\section{COMPLICATIONS OF VACCINATION}

In this Lecture I have already alluded to certain complications of vaccination, for as Dr. D. Thomson has remarked in his Milroy Lecture, ${ }^{21}$ the history of smallpox shows that no vaccine is absolutely safe. When virulent attacks of smallpox were to be feared and the majority of survivors scarred and disfigured by the disease, complications, which occasionally arose, were seldom diagnosed. If they were, it was considered that national protection from so deadly a disease far outweighed the risk. Some un-vaccinated persons, again, will exhibit adverse reactions to any antigen; probably, because of some defect in their immunological defence system, either hereditary or induced by illness (Thomson). The following are the chief complications of vaccination:22

(1) Benign Generalized Vaccine. In 196514 cases were reported, all associated with vaccination done under Section 26 of the National Health Service Act. All recovered.

(2) Septicaemia and Sepsis. These complications should not occur with proper aseptic precautions in vaccinating. It was noted that the introduction of glycerinated calf lymph in the nineteenth century greatly diminished septic complications, another outstanding tribute to Copeman's work.

(3) Post Vaccinial Encephalomyelitis. It was known for many years that, in a small proportion of persons vaccinated, lesions of the central nervous system occurred which caused encephalitis. The same manifestation, although rare, may appear after smallpox, scarlet fever or some other infectious disease. In 1926 the Minister of Health in conjunction with the Medical Research Council appointed a Committee under the chairmanship of Sir Humphry Rolleston, P.R.C.P., which reported in 1928 and 1930 . The main advice was for one insertion to be made in secondary vaccination. Encephalomyelitis is still a serious complication of vaccination. Three cases were reported by medical officers of health in 1965. One case in a child of 15 months after primary vaccination was fatal. The other two cases followed revaccination in adult males and rapidly recovered.

(4) Eczema. A few instances of this complication may occur, usually in young children, although adults are sometimes affected. Under treatment good recoveries are the rule.

(5) Progressive Vaccinia (vaccinia gangrenosa). One case of this rare and grave complication occurred in 1963 in an Iraqi child of ten months who had been vaccinated in Iraq ten days previously. The left forearm had to be amputated. Thrombocytopenic purpura developed and the child died.

(6) Thrombocytopenic purpura. Another example of this rare complication was seen in 1965 in a boy of 12 months. The platelet count improved steadily during the subsequent three weeks.

I would once more emphasize that these complications of vaccination are extremely rare, and as with all prophylactic vaccines are to be far counter-balanced by the protection gained, in this case, against so devastating a disease as smallpox. Indeed, the majority of complications can be guarded against and in those that occur the patient usually recovers. At the same time these truths afford little consolation to the individual parent whose child dies after vaccination. 
Medical research is not neglectful of this problem. Recently, experimental trials of tissue culture preparations have been encouraging, and with improved technique such preparations may still further reduce the risk of complications after vaccination. Another method with a similar aim is to use a purified inactive virus, with adjuvant, injected subcutaneously. Research for an even safer and more effective vaccine, therefore, continues. In opening this path, as we have seen, Copeman has been the pioneer through his scientific experiments.

OF THE NON-REAPPEARANCE OF EXTENSIVE VIRULENT EPIDEMICS OF SMALLPOX

When in 1898 conscientious objectors were allowed by Act of Parliament to be exempt from compulsory vaccination, the clause was liberally interpreted and the number of infants vaccinated steadily declined. Grave fears were expressed by medical experts and medical officers of health that this latitude would bring back the epidemics which ravaged Great Britain before compulsory vaccination. Sir Rider Haggard wrote a novel in 1898, entitled Doctor Therne, ${ }^{23}$ in which he described such an epidemic, observing that 'some who are very competent to judge say that this action must result hereafter in much terror, and in the sacrifice of innocent lives ... helpless children from which the State has thus withdrawn its shield.'

In the years between 1898 and 1946 the numbers of vaccinated children ebbed and flowed. Small outbreaks of smallpox and alastrim occurred and were controlled by public health measures. Then in 1946, as already mentioned, compulsory vaccination was abolished.

The figures for 1965 are not completely comparable with those of previous years, since the 5-14 age group has been enlarged to 5-15 and figures for people over 15 are no longer available. They do, however, show an increase in primary vaccinations of pre-school children and in revaccinations of school children. The total number of children vaccinated in the first two years of life is still only 33 per cent of this agegroup. This shows but a slight advance on the 1964 figure of 32 per cent. ${ }^{22}$

Why is it that the dreaded epidemics of smallpox have not reappeared? The reasons, I suggest, are the following:

(1) Two world wars have caused a large number of persons of both sexes to be vaccinated. As a result the spread of infection is blocked. (2) When smallpox appears in this country, a large number of persons, unvaccinated, rush to be vaccinated, thus again diminishing spread of the disease by contact infection. (3) Above all there is the careful watch kept by Port Health authorities, the isolation of patients in smallpox hospitals and the ceaseless vigilance of medical officers of health and their staffs to detect primary cases of smallpox and to prevent spread of the disease.

\section{SPEED OF AIR TRAVEL AND IMPORTED SMALLPOX}

The potentialities of a virulent outbreak of smallpox still exist, and the danger of imported smallpox entering Great Britain from countries where smallpox is endemic have been increased by the speed of modern air travel. This was tragically illustrated in December 1961 and January 1962 when five travellers from Pakistan developed smallpox in this country from which two of them died. There followed 62 indigenous cases-16 in England and 46 in Wales-and of these 24 died. No less than 


\section{Prevention of Smallpox: From Edward Jenner to Monckton Copeman}

41 of the indigenous cases occurred in persons who were hospital patients, either at the time when the diagnosis was made or when infection was believed to have occurred, or were members of hospital staffs or visitors to wards involved. A hospital pathologist, an obstetrician and a hospital cook, none of whom had been vaccinated before infection was acquired, all contracted smallpox and died therefrom, an unvaccinated nurse also developed the disease but in this case it was not fatal. Vaccination and revaccination throughout life at certain times are still all important. ${ }^{24}$

The prevention of infectious disease, including smallpox, is one of the chief responsibilities of a local authority. It is not generally realized by the public, unaware of the days when epidemic outbreaks and pestilence rioted often unchecked in this country, how much they owe to public health authorities and their medical officers for the ceaseless vigilance they maintain.

\section{CONCLUSION}

I have now endeavoured to tell you something about the history of the prevention of smallpox. Its success has been due to the scientific knowledge, experiments and courage of two great and good men-Edward Jenner and Sydney Arthur Monckton Copeman. They rest from their labours but their works do follow them and adorn British Medicine.

\section{REFERENCES}

1. Copeman, P. M., Letter on 'Insanity of King George III', Brit. med. J., 1966, ii, 304.

2. MACAlPINE, IDA, and HUNTER, RICHARD, 'The insanity of King George III; a classic case of porphyria', Brit. med. J., 1966, i, 65.

3. Copeman, S. M., 'Contribution to a discussion on lead poisoning from drinking water', Brit. med. J., 1890, ii, 498.

4. Idem., Report on Public Health and Medical Subjects, Ministry of Health Reports, No. 31, 1925.

5. MacNalty, A. S., and Craigie, J., 'Sydney Arthur Monckton Copeman, 1862-1947', Obituary Notices of Fellows of the Royal Society, 1948, 6, 37-50.

6. MacMichael, W., 'Sydenham', Lives of British Physicians, London, Murray, 1830, p. 89.

7. Copeman, S. M., Vaccination: its Natural History and Pathology (Milroy Lectures, 1898), London, 1898, pp. 19, 20.

8. Munk, W., 'Thomas Dimsdale', Roll of the Royal College of Physicians, London, 1878, vol. II, p. 232.

9. LefanU, W. R., A Bio-Bibliography of Edward Jenner, 1749-1823, London, Harvey and Blythe, 1951.

10. JENNER, E., An Inquiry into the Causes and Effects of the Variolae Vaccinae, A Disease discovered in some of the Western Counties of England, particularly Gloucestershire, and known by the name of the Cow Pox, London, Sampson Low, 1798.

11. Jenner Centenary Number, Brit. med. J., 1896, ii, 1245-1312.

12. Drewirt, F. D., The Life of Edward Jenner, M.D., F.R.S., Naturalist and Discoverer of Vaccination, London, Longmans, 1933.

13. Parish, H. J., A History of Immunization, Edinburgh and London, E. \& S. Livingstone, 1965, p. 43.

14. Hutchinson, J. R., 'A historical note on the prevention of smallpox in England and the foundation of the Government Lymph Establishment', Report of the Ministry of Health for the year ended 31 March 1946, including the Report of the Chief Medical Officer on the State of the Public Health for the year ended 31 December 1945, cmd. 7119, London, H.M. Stationery Office, 1946, appendix A, 119-130. 
Sir Arthur S. MacNalty, K.C.B.

15. Creighton, C., A History of Epidemics in Britain, 2nd ed., ed. by D. E. C. Eversley, with a biographical memoir by E. Ashworth Underwood, London, F. Cass, 1965. For smallpox see vol. I, chapter 9, p. 439, and vol. II, chapter 4, p. 434.

16. Copeman, S. M., and MANN, G., 'The histology of vaccinia', Report of the Medical Officer of Health, Local Government Board, (1898-1899), 1988, 28, 505-546.

17. Copeman, S. M., 'The relationship of smallpox and alastrim', Proc. Roy. Soc. Med., 1919-1920, 3, sect. Epidemiology and State Medicine, 237-260; and in First Annual Report of the Chief Medical Officer, Ministry of Health, 1920, Appendix II, 271-282.

18. 'Mild smallpox', Brit. med. J., 1966, i, 1248.

19. 'Diagnosis of variola minor', Brit. med. J., 1966, ii, 255.

20. Marsden, J. P., London County Council Report, no. 3209, 1936. Reprinted in Bull. Hyg. Lond., 1943, 23, 735.

21. Thomson, D., 'Mass immunization in the control of infectious disease', (Milroy Lectures, abridged, 1966), Brit. med. J., 1966, ii, 427-43.

22. Annual Report of the Chief Medical Officer, Ministry of Health, for the year 1965, 1965, pp. 58, 59.

23. HAGgARD, H. R., Doctor Therne, London, Longmans, Green, 1898.

24. 'Smallpox, 1961-1962', Report on Public Health and Medical Subjects, Ministry of Health, 1963, no. 109. 